\title{
Good Neighbors but Bad Employers: Two Faces of Corporate Social Responsibility Programs
}

\author{
Heung-Jun Jung • Dong-One Kim
}

Received: 25 September 2013/ Accepted: 23 February 2015/Published online: 6 March 2015

(c) The Author(s) 2015. This article is published with open access at Springerlink.com

\begin{abstract}
Using two firm-level datasets in Korea, we analyzed the effects of corporate social responsibility (CSR) on employment relations. We propose that participation in corporate social activity may not necessarily reflect an ethical commitment to do "the right thing," but instead can be associated with mobilizing internal resources to offset the costs imposed by external CSR involvement undertaken because of social pressure. Analysis of the two datasets showed similar results. The results demonstrate that socially responsible actions facilitate employer tendency to use performance-based pay and efficiency-based work practices. We also find that CSR has a negative association with employment growth and increased labor flexibility through contingent employment. These findings shed light on the internal impact of CSR involvement on a firm's employment policies with respect to resource allocation.
\end{abstract}

Keywords Corporate social responsibility - Employment relations - Resource allocation - Efficiency-based works · Performance-based pay $\cdot$ Labor costs

\section{Introduction}

As firms encounter intensive pressure from consumers, community groups, and NGOs while simultaneously facing heightened competition in the global economy, they are

\footnotetext{
H.-J. Jung · D.-O. Kim ( $₫)$

Business School, Korea University, 5-1 Anam-dong, Sungbukgu, Seoul 136-701, Korea

e-mail: dokim@korea.ac.kr; dokim64@hotmail.com

H.-J. Jung

e-mail: hjun.jeong@gmail.com; yoon2@korea.ac.kr
}

increasingly compelled to acknowledge the demands of corporate social responsibility (CSR). Although CSR activities have greatly increased in recent years, conceptual and empirical research on CSR during the last four decades has mainly examined the relationship between CSR and financial performance (Cochran and Wood 1984; McWilliams and Siegel 2000; Pava and Krausz 1996; Waddock and Graves 1997). As a result, research on CSR has been criticized for ignoring the relationships between CSR and other factors (Campbell 2007; Margolis and Walsh 2003).

One of these largely uninvestigated factors is the impact of CSR on employment relations. The lack of empirical research in this area, despite the importance of employees as stakeholders in business organizations, is in sharp contrast to the recently escalating interest in the ethics of human resource management (Inyang et al. 2011; Guest and Woodrow 2012).

Within the realm of the research that has been undertaken on this topic, two contrasting indications have emerged concerning the association between CSR and employees. From a social identification perspective, a few recent empirical studies have suggested that organizational CSR improves employee job satisfaction (De Roeck et al. 2014), organizational commitment (Brammer et al. 2007), and human resource retention (Jones 2010). On the other hand, several qualitative studies have treated CSR as part of a corporate propaganda strategy that can easily ignore the interests of employees affected (Deakin and Hobbs 2007; Hillman and Keim 2001). Consequently, these empirical inconsistencies have raised the need for a better comprehension of the relationship between CSR and employment relations. In line with this thinking, Jamali and Mirshak (2007) have suggested the need for quantitative research on the effects of CSR on employment relations at the firm-level. Nevertheless, empirical studies on the 
impact of CSR on employment relations remain scarce (Rodrigo and Arenas 2008).

The current paper, intended to fill this research gap, proposes an alternative framework for examining the relationship between CSR and employment relations. From a resource allocation viewpoint, this study analyzed the effect of CSR on various employment relations outcomes such as performance-based wages, efficiency-based work practices, employment growth, restructuring, and contingent employment. Proposed hypotheses were tested using two kinds of Korean firm-level datasets. This study first describes the institutional context: CSR in Korea. Theoretical perspective, hypotheses, analyses, and empirical results follow. Finally, there is a discussion of findings, conclusions, and implications.

\section{Institutional Context: CSR in South Korea}

Over the past few decades, Korean firms have drastically revised their business strategy on CSR from traditionalism to globalization. Engaging in CSR activity to improve a firm's reputation is now a popular business strategy (Kim and Choi 2013). For instance, the total CSR expenditure of the top 220 Korean firms has increased from USD 1.9 billion in 2008 to USD 2.5 billion in 2010 (Federation of Korean Industries 2011). Moreover, the Federation of Korean Industries, an organization of employers, has reported that a majority of the largest 500 Korean companies have enacted a code of ethics (Federation of Korean Industries 2011).

Managerial awareness of CSR in Korea stems largely from changing business environments because of rapid globalization. This trend has facilitated the rapid spread of CSR in Korea. That is, Korean firms have become more globalized since the early 1990s. For instance, foreign direct investment by Korean multinational corporations (MNCs) increased from about USD 1068 million in 1990 to over USD 25,590 million in 2011 (Korea Eximbank 2012). This change has required Korean MNCs to adopt and adhere to global standards in response to social demands in host countries. Thus, CSR undertaken by large Korean firms has involved efforts to improve ethical business practices such as management transparency, improved corporate governance, and integrity in accounting.

Despite this increase in CSR activity, controversy exists as to whether CSR can improve the interests of both internal and external stakeholders. Whereas corporate managers argue that CSR in Korea has benefited the well-being of employees, others believe that these policies have been instituted merely for public relations and largely ignore the interests of employees (Choi et al. 2010). For instance, in a study of 30 Korean companies, Welford (2005) demonstrated that their CSR programs focused on external social issues rather than internal labor standards. We believe that the recent dramatic growth in CSR activities and the debate on their impact on internal stakeholders render the Korean case a suitable research setting for the present study.

\section{Theoretical Perspective and Hypotheses}

Although academic debates over the last four decades have reached no clear consensus, CSR can be roughly defined as follows: Being closely related to the social expectations of corporations (Zenisek 1979), CSR involves multidimensional decision-making beyond the economic interests of the business (Carroll 1979, 1991) or legal requirements (McWilliams and Siegel 2001). Since scholars have defined CSR in different ways, some researchers have attached strategic implications to CSR without regard for its alleged altruism. For example, Porter and Kramer (2006) argued that corporate attention to CSR is not entirely voluntary but involves strategic decision-making. According to their perspective, involvement in socially responsible activity within competitive business environments is not voluntary but a compelling strategic choice. This strategic view stems from societal expectations that perceive CSR involvement as a signal of corporate legitimacy. In the same vein, managers want CSR to be directly linked to performance ( $\mathrm{Zu}$ and Song 2009), and CSR is certainly related to managerial concerns about the bottom line.

\section{CSR and Employment Relations from a Resource} Allocation Perspective

Resource is a paramount concern for managers attempting to implement CSR programs. One can easily see the importance of resource availability in pursuing CSR. Despite the importance of resource availability in implementing corporate responsibility programs, there is a dearth of scholarly attention in resource allocation decision in implementing specific social responsibility programs. The present paper tries to explain the effects of CSR programs on employment relations by exploring its integration with the conceptual framework of resource allocation decisions within firms.

The burden of obtaining resources for participating in CSR within a competitive business environment is always a concern for management. Indeed, Freeman (1984, pp. 38-40) confirmed the relationship between CSR and available resources, as "CSR is often looked at as an "add on" to "business as usual" and the phrase often heard from executives is "CSR is fine, if you can afford it." "Since management has to consider both benefits and additional 
costs for CSR, the situation of 'catch 22 ' in the adoption of CSR program frequently occurs (Jamali et al. 2009).

Needless to say, corporations need resources to respond to recent global trends, such as the adoption of codes of conduct and ISO26000. Some costs resulting from CSR activities are not directly financial (such as environmental protection) but nonetheless frequently impose monetary burdens such as investment in green technologies; others are directly financial, such as donations to charities and the creation of scholarship funds (Aupperle et al. 1985). As Campbell (2007) distinguished between lip service for CSR and substantive activities requiring significant internal resources, socially responsible actions impose considerable costs. Parkinson (2003) also noted that CSR is often controlled by economic conditions rather than by managerial choices. Therefore, maintaining a good reputation through CSR in a competitive environment depends on a firm's resources to a certain degree.

A management committed to social issues is likely to work toward mobilizing available resources. Firms increase CSR involvement when they have adequate financial resources (Ullmann 1985; Waddock and Graves 1997). If they do not have sufficient resources for CSR initiative, however, management must mobilize other resources for maintaining CSR programs that satisfy social expectation. In particular, because involvement in social activity for external stakeholders results in higher social expenses than noninvolvement, firms pay attention to effective and efficient use of resources. We used the logic of resource allocation in formulating the theoretical framework and hypotheses of our study.

\section{Hypotheses}

An important point here is that mobilizing resources in response to social responsibilities may sometimes conflict with the interests of employees. Although employees are obviously one of the stakeholders and a few studies based on a normative perspective have given attention to the positive link between socially responsible actions and outcomes of employment relations, questions are arising as to the possibility of balancing the interests of all stakeholders, given the limited resources (Sternberg 1997).

During the process of resource mobilization, for example, firms can undertake cost cutting that may be detrimental to working conditions. If CSR is adopted as part of a corporate propaganda strategy, the interests of employees are more like to be ignored or sacrificed. Indeed, previous studies have indicated that although firms were involved in CSR activities, they often ignored their responsibilities to their employees (Aupperle et al. 1985; Pava and Krausz 1996). Hillman and Keim (2001) asserted that employers frequently regard CSR as an obligatory response to external issues rather than as an obligation to their employees. Deakin and Hobbs (2007) also argued that employers tended to see CSR as concerned with external social issues and unrelated to internal employment issues. Similarly, IBM, the famous multinational company, has a long reputation for its involvement in CSR, but was forced to offer its employees early retirement, buyouts, and undesirable transfers in order to maintain organizational effectiveness (Cottrill 1990). Therefore, CSR itself may not benefit employees.

Wood (1991) highlighted the importance of a balanced CSR activity based on three dimensions: individual choice (e.g., managerial preferences), organizational responsibility (e.g., firm-specific interests), and institutional necessity (e.g., general obligations). However, qualitative research has demonstrated that because of a lack of resources, balanced CSR activities in all three dimensions are rarely achievable and thus not adopted (Cooper and Owen 2007; Cottrill 1990; Hillman and Keim 2001; Vogel 2006). In many cases in which a choice must be made between external and internal demands, a firm must consider external demands first because of the inability, over concern for its reputation and public image, to withdraw from social activities. As a result, firms are increasingly directing their CSR activities into external social issues, especially when social demands are strong and the requisite internal resource is not available.

A business primarily has two options to mobilize its resources. One is to improve its organizational efficiency. The other is to reduce its internal costs. From a strategic business perspective, the goal of mobilizing resources is to generate resource reserves through both efficiency enhancement and cost minimization. Good examples of the former include efforts to increase productivity by using innovative work systems and/or undertaking practices to enhance employee motivation. These practices are closely associated with generating tangible and intangible resources by using employee knowledge and creativity through employee involvement programs and various incentives to motivate employees. Cost minimization is associated with reducing operating costs including labor costs. It can involve adoption of more flexible utilization of human resources such as organizational restructuring and the use of a contingent labor force. In general, a contingent labor force is likely to be associated negatively with the interests of employees.

In formulating our hypotheses, we first considered the methods that firms may adopt to improve organizational efficiency to mobilize resources for CSR. The majority of the literature mentioned that performance-based pay is one popular way for organizations to enhance organizational performance. Pay-for-performance is a monetary incentive pay system in which employee compensation is related to 
job performance. Performance-based pay includes individual merit-pay, gainsharing, and profit sharing. The number of companies adopting pay-for-performance in Korea has been steadily increasing since the late 1990s, and over $50 \%$ of all Korean companies were reported to connect at least part of an employee's pay to measures of performance (Shin et al. 2014). Since monetary rewards are the main incentive for increased productivity, quality, and customer service, pay-for-performance is considered as a powerful motivator in enhancing organizational performance by motivating and reinforcing the rewarded behavior.

Firms needing resources for CSR programs such financial donations have to improve short-term financial performance by adopting performance-enhancing programs. We determine that corporations implementing CSR programs are likely to adopt pay-for-performance because it motivates employees through material, i.e., monetary, incentives. This is why that the financial performance of firms with pay-for-performance is superior to that of firms without it and previous empirical studies support this claim (Abowd 1990; Delery and Doty 1996; Lee et al. 2011; Origo 2009). For example, Origo (2009), using data from Italian metalworking firms, found that performance-related pay contributed to increases in productivity in the range of 7-11\%.

More specifically, prior literature has reported a significant relationship between CSR and incentive-based compensation (Falck and Heblich 2007; Mahoney and Thorne 2005). Also, Jones et al. (2007), in their case study involving Australian companies, found that the extent to which a firm is involved in CSR was directly correlated to its adopting a performance-based wage system. Therefore, we are safe in assuming that firms oriented to CSR involvement are more likely to adopt performance-based pay than firms without CSR involvement. Based on this reasoning and on previous empirical results, we formulated the following hypothesis:

Hypothesis 1 The degree of involvement in CSR will be positively related to the adoption of performance-based pay.

We also believe that firms with CSR activities are more likely to adopt efficiency-based work practices because these firms seek to recoup social costs through improved productivity and enhanced quality. Indeed, one way to recoup the costs incurred through socially responsible actions is to increase internal efficiency through innovative work practices that improve organizational performance. Previous studies have generally shown that efficiency-based work practices such as self-autonomous teams, quality circles and job rotations contributed positively to a firm's performance. These practices heightened employees morale and satisfaction and increased motivation through involvements and better communication that in turn leads to heightened utilization of previously untapped knowledge and creativity within the workforce (Ichniowski et al. 1996; Neumark and Cappelli 1999). In a similar context, Paul and Siegel (2006) argued that managers tend to implement internal efficiency practices along with CSR programs because they expect the benefits of workplace innovation to exceed the costs associated with socially responsible activity. Vitaliano and Stella (2006), in their empirical study using data from the banking industry, also found that firms adopted practices aimed at maximizing internal efficiency to offset the costs of socially responsible activity. Based on the evidence from these studies, we hypothesized that firms engaged in CSR are more likely to adopt efficiency-based work practices than those without CSR.

Hypothesis 2 The degree of involvement in CSR will be positively related to the degree of adaptation of efficiencybased work practices.

Next, we also constructed hypotheses regarding how firms pursuing CSR activities attempt to use various means to minimize operating costs. CSR costs undertaken by a firm to solidify its public reputation and image seem to facilitate implementation of a labor cost minimization strategy. If firms cannot reduce such external obligations as CSR, they may instead implement a cost-cutting strategy to decrease internal costs such as labor. In this context, prior case studies have observed a tendency of management to separate responsibility to employees from strategic CSR for social issues (Hillman and Keim 2001; Fenwick and Bierema 2008). That is, when a firm cannot maintain CSR activities for both internal and external stakeholders, management tends to pursue CSR activities exclusively for external stakeholders. The activities likely to be continued include environmental protection, donations, and scholarships.

In the same vein, the current study predicts a negative relationship between CSR activities and employment growth. Although new employee recruitment is important in terms of corporate social obligations to both employees and society, businesses participating in CSR may be wary of adding personnel because they must anticipate the expense involved in CSR activities as well as plan for any unexpected future reduction in product demand. For management, a larger employment roster implies a considerable increase in short-term and long-term labor costs; these costs include recruitment, selection, training, compensation, and safety and health. In many cases, management regards labor as a quasi-fixed cost. Indeed, several case studies have shown either that CSR and employment are unrelated (Deakin and Hobbs 2007), or that CSR is positively related to employee reduction in special situations (Benson 2008). Overall, we believe that firms 
participating in CSR tend to have a more conservative employment policy than others and are less likely to experience employment growth:

Hypothesis 3 The degree of involvement in CSR will be negatively related to employment growth.

According to $\mathrm{Zu}$ and Song (2009), managers perceive CSR as a financial burden, and when they have to become involved in CSR activities, they first examine their financial situation. When a firm faces additional outlays for CSR to avoid violating its societal obligations, it is likely to concentrate on more profitable practices that also improve organizational efficiency through reductions in labor costs. One way to reduce labor costs is to seek numerical flexibility, and organizational restructuring is one of the most widely used practices to achieve this. In general, restructuring has been regarded as a sure way to gain short-term financial savings when facing financial constraints. Thus, we opine that firms with CSR are more likely to restructure as a means to cope with CSR expenses.

The previous literature supports our proposition. For instance, Bonvin's (2007) case study in Switzerland described how a firm involved in CSR did not hesitate to lay off employees when it was short of liquid assets. Vogel (2006) also found that many global companies made social contributions in developing countries at the expense of their employees' job security in the parent country. These studies suggest that firms meeting external demands for social activities may have to resort to organizational restructuring to minimize labor costs. This view highlights a positive association between CSR and organizational restructuring in externally socially responsible firms. Pursuit of this line of reasoning leads to the following hypothesis:

Hypothesis 4 The degree of involvement in CSR will be positively related to organizational restructuring.

Another means of securing labor flexibility is the usage of contingent workers. Although contingent employment arrangements have been criticized for the insecurity and vulnerability for employees, use of nonstandard forms of employment may convey explicit advantages to contemporary corporations. This is because contingent employment provides firms with labor flexibility while typically lowering labor costs. This labor arrangement confers flexibility because contingent workers can be more easily terminated than permanent employees, enabling rapid adjustment in labor to respond to changes in business conditions. Labor costs are typically lower in this arrangement because workers are paid less. We expect that CSR participation relates positively to the use of contingent employment. It is believed that firms undertaking social commitments such as making contributions and providing community services prefer workforce flexibility in which contingent employment is seen as an instrument to offset social costs. Indeed, previous case studies have presented the possibility that conditions of resource constraints juxtapose CSR involvement and contingent employment. Smith and Helfgott (2010) reported a case in which top management in a firm promised CSR policies focusing on community relations and environmental protection but concomitantly reclassified $70 \%$ of its workforce from permanent to temporary contracts. In particular, CSR involvement may accelerate the usage of contingent employment in certain geographic regions (such as in Asia and Latin America) where legal protection of contingent employees is limited. In such countries, the cost of social expenses can easily be transferred to labor in the form of contingent employment. For these reasons, we formulated the following hypothesis:

Hypothesis 5 The degree of involvement in CSR will be positively related to the use of contingent employment.

Taken together, we proposed the following theoretical framework for the impact of CSR on employment relations (see Fig. 1).

\section{Research Methods}

In the present paper, we utilized two different datasets to construct a comprehensive picture on the effects of CSR on employment relations. While Study 1 included only listed firms that were relatively large and have well-developed CSR programs, Study 2 included a representative sample of all firms with more than 30 employees in Korea. By analyzing two different datasets, the results can be expected to be less biased and have greater generalizability. If different datasets provide consistent results, the resultant findings can expect greater credibility.

\section{Study 1}

\section{Sampling}

The analysis in this study was performed at the firm level. The sample was drawn from the CSR Index of the Korea

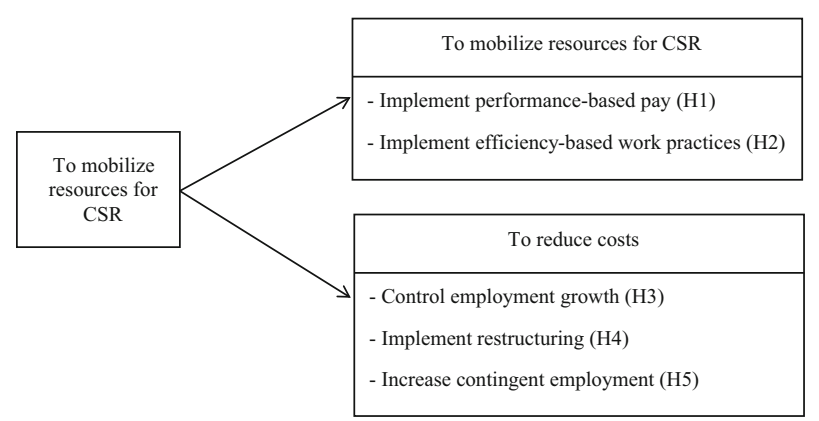

Fig. 1 A theoretical framework for CSR 
Economic Justice Institute (KEJI). Established in 1990, KEJI is one of the leading nongovernmental organizations in Korea. KEJI has evaluated the CSR activities of publicly listed firms annually since 1991, and each company is rated on multiple attributes deemed relevant to CSR. The KEJI index covers about 350 publicly listed Korean companies and annually discloses the scores of Korea's top 200 firms in terms of CSR. The KEJI index excludes banks, mutual fund companies, and real estate investment firms because these firms have very different financial and accounting systems and business environments from other firms such as those in manufacturing, transportation, and construction. Data for 5 years (2005-2009) on the firms comprising the KEJI Index made up the dataset analyzed in this study. This study examined 251 firms that were listed in the top 200 at least twice during the 5-year period. After excluding 17 firms that had gone out of business or merged during the study period, 234 firms remained in our final sample.

CSR evaluation using the KEJI index has a special advantage. This dataset has CSR performance ratings since 1991 and thus a depth of data useful for longitudinal analysis to investigate CSR trends. Indeed, the KEJI index was the first comprehensive, multidimensional CSR rating developed in Korea. It is comparable to the index of the Council on Economic Priorities in the U.S., the Corporate Responsibility Index in Australia, and the Asahi Foundation Index of Japan (Choi et al. 2010). The KEJI index is also similar to the index of Kinder, Lydenberg, and Domini (KLD), which has rated the firms of the S\&P 500 (firms) index on seven CSR categories since 1991.

\section{Measurement}

The present study collected data from four sources: the KEJI index, telephone survey, business reports of firms, and archival data from the Ministry of Labor and Employment in Korea. First, the KEJI index evaluates seven qualitative areas (i.e., corporate governance, corporate justice, economic contribution, community relations, customer satisfaction, employee relations, and environmental protection) based on 38 CSR items. The KEJI index is based on publicly available data of the stock market and other sources such as business reports. The KEJI index used a modified version of items taken from studies by Graves and Waddock (1994).

CSR activity was measured through the eight items of the KEJI index listed below. These items can be classified into three categories: community service, environmental protection, and customer satisfaction related to social issues. These eight items are as follows: amount of charitable donations (this item belongs to community relations); energy efficiency in the workplace, environmental violations, public disclosure of environmental violations, and rewards related to environmental protection (these four items belong to environmental protection); and, lastly, certificates of service, certificates of quality, and reductions in the growth of advertising (these three items belong to customer satisfaction). Each of the eight items was rated with standardized values calculated from the original scores. ${ }^{1}$ Two categories of values, $0-2$ and $0-3$, were used for these eight items. The scale from 0 to 2 was used for energy efficiency, public disclosures about environmental violations, certificates of service, and reductions in the growth of advertising. The scale from 0 to 3 was applied to amount of charitable donations, rewards related to environmental protection, environmental violations, and certificates of quality. Therefore, the total possible score of CSR as the sum of the above eight items ranged from 0 to 20 .

Second, we conducted a telephone survey to collect data for dependent variables such as performance-based pay, efficiency-based work practices, and contingent employment. Human resources managers in the 234 firms were surveyed in this way. We collected data for the past 5 years (2005-2009) because firms usually had HR records for this period. The telephone survey was conducted between April 1, 2011, and October 1, 2011. Completed questionnaires were collected from 166 firms (response rate: $70.94 \%$ ) after several follow-ups. The 166 firms included 88 unionized and 78 nonunion organizations. The performance-based pay variable was measured by the existence of an individual merit-pay system, gainsharing, or profit sharing program, as used in the study by Brown (1990). If a firm had an individual merit-pay system, it was coded as 1 (otherwise 0 ). If a firm had a gainsharing or profit sharing program, it was coded as 1 (otherwise 0). The performance-based pay variable was calculated by the sum of the two variables above, ranging from 0 to 2 . Efficiency-based work practices were obtained from HR managers and were measured by three items used by Osterman (1994). The three items are: team, QC activity, and job rotation. Responses were rated from 0 (nonexistent) to 1 (existent). All three items were summed, and the variable, efficiencybased work practices, was rated on a scale of $0-3$. The contingent employment variable was calculated as a percentage of the sum of part-time and fixed-term employees

\footnotetext{
1 All items of the KEJI index were standardized by the following process: First, a standardized value was created by two methods. One is linear interpolation, which is a method of curve fitting using linear polynomials $\left\{y=y_{\min }+\left(y_{\max }-y_{\min }\right)\left(x-x_{\min }\right) /\left(x_{\max }-x_{\min }\right)\right\}$. The second is a method using interval scales (i.e., A, B, C, D, and E). Both methods are dependent on characteristics of the original data. For example, the interpolation standardization is used when the original data have few missing values and have a standard normal distribution. On the other hand, standardization using the interval scale is applied when the original data have many missing values and their distribution is skewed. Second, final values are obtained by calculating the weighted rate of each item.
} 
per the total number of employees. These data were also drawn from the responses of HR managers.

Third, the business reports of the sample firms were sources of data for several variables. Employment growth was obtained from the business reports and calculated as the total number of employees in the previous year divided by the present number of employees. Organizational restructuring was measured by dichotomous categories used by Ahmadjian and Robinson (2001), who defined restructuring as a decrease in the number of permanent employees by more than $5 \%$ from the previous year (between year $t-1$ and year $t$ ). Organizational restructuring was measured by whether employee numbers declined by more than $5 \%$ from one year to the next (coded 1 if true, 0 if not) (between 2004 and 2005, 2005 and 2006, 2006 and 2007, 2007 and 2008, and 2008 and 2009, respectively).

Control variables, which may have accounted for some variations in the dependent variables at the firm level, were also collected from business reports. We controlled for firm-specific characteristics (i.e., firm size, ratio of production/operation workers and unionization, if any) that may influence a firm's employment relations policies and strategies (Evans 1987). Firm size was measured as the natural $\log$ of the number of total employees. The ratio of production/operation workers was measured as a percentage of the number of production/operation workers divided by the total number of employees. The degree of foreign ownership was controlled to reflect the corporate governance structure because foreign ownership exerts a considerable impact on employment relations (Slaughter 2007). Foreign ownership was measured as a percentage of the number of foreign-owned stock divided by the total amount of stock. Financial variables such as sales growth and labor costs per worker were controlled because overall financial performance plays a role in shaping employment relations policies and strategies (Huselid 1995). The sales growth variable was calculated as the percentage growth in sales in a given year compared with the preceding year. Also, labor costs per worker were measured by dividing the amount of total wages by the number of total workers.

Finally, data related to labor unions were provided by the Ministry of Labor and Employment in Korea. The union variable was measured as a dummy variable and coded as "nonexistent" (coded 0) or "existent" (coded 1).

\section{Analyses}

We used STATA (13.0 version) for unbalanced panel data analysis. In general, a longitudinal data analysis provides several advantages (Baltagi 2008). First, pooling multiple observations for each firm increases both sample size and degrees of freedom. Further, temporal effects that are not detectable in a cross-sectional analysis can be controlled.
More importantly, the panel data enable us to reduce multicollinearity in linear regression analyses. The selection of the appropriate model in panel data analysis is important to ensure correct estimation, because the fixed and random effects models represent different assumptions about data. In general, if researchers analyze a population that has heterogeneity within entities, the fixed effect model is considered appropriate, whereas they analyze the randomly chosen or stratified sample, the random effect model is regarded suitable (Behrman and Wolfe 1989). Since the present analyses dealt with the population of firms with socially beneficial CSR activities, fixed effect models were considered more appropriate (Borenstein et al. 2011). Fixed effects regressions were used to test Hypotheses 1, 2, 3, and 5. For Hypothesis 4, a logistics regression model was used because the dependent variable, organizational restructuring, was a $0-1$ nominal variable. In all models, control variables were included because of their possible influence on employment and HRM practices.

\section{Results}

Descriptive statistics and correlations for all variables are presented in Table 1.

All hypotheses were empirically supported. Table 2 presented the relationships between CSR and dependent variables. First, the regression coefficient of the CSR variable on performance-based pay was positive and significant $\left(\beta=.02, p<.01, R^{2}=.11\right)$. Also, CSR has a positive and significant relation with efficiency-based work practices $\left(\beta=.02, p<.05, R^{2}=.06\right)$. Thus, Hypotheses 1 and 2 were supported. Overall, these results indicated that firms participating in socially responsible activities may enhance internal efficiency through various HRM practices. In addition, three CSR index categories (i.e., community relations, customer satisfaction, and environmental protection) on dependent variables were individually estimated. In general, the individual estimations showed weak, but hypothesized relationships between independent dependent variables. While community service has significant and anticipated relationships with both performance-based pay and efficiency-based work practices, customer satisfaction activities were not significantly related with HR policies for organizational efficiency. Environmental protection showed a significant and positive relationship only with performance-based pay. Taken together, the results tend to show that the more firms participated in external CSR activities, the more they relied on strategies that enhanced internal efficiency.

Second, we tested the effects of CSR on employment growth, organizational restructuring, and the usage of contingent employment. The relationship between CSR 


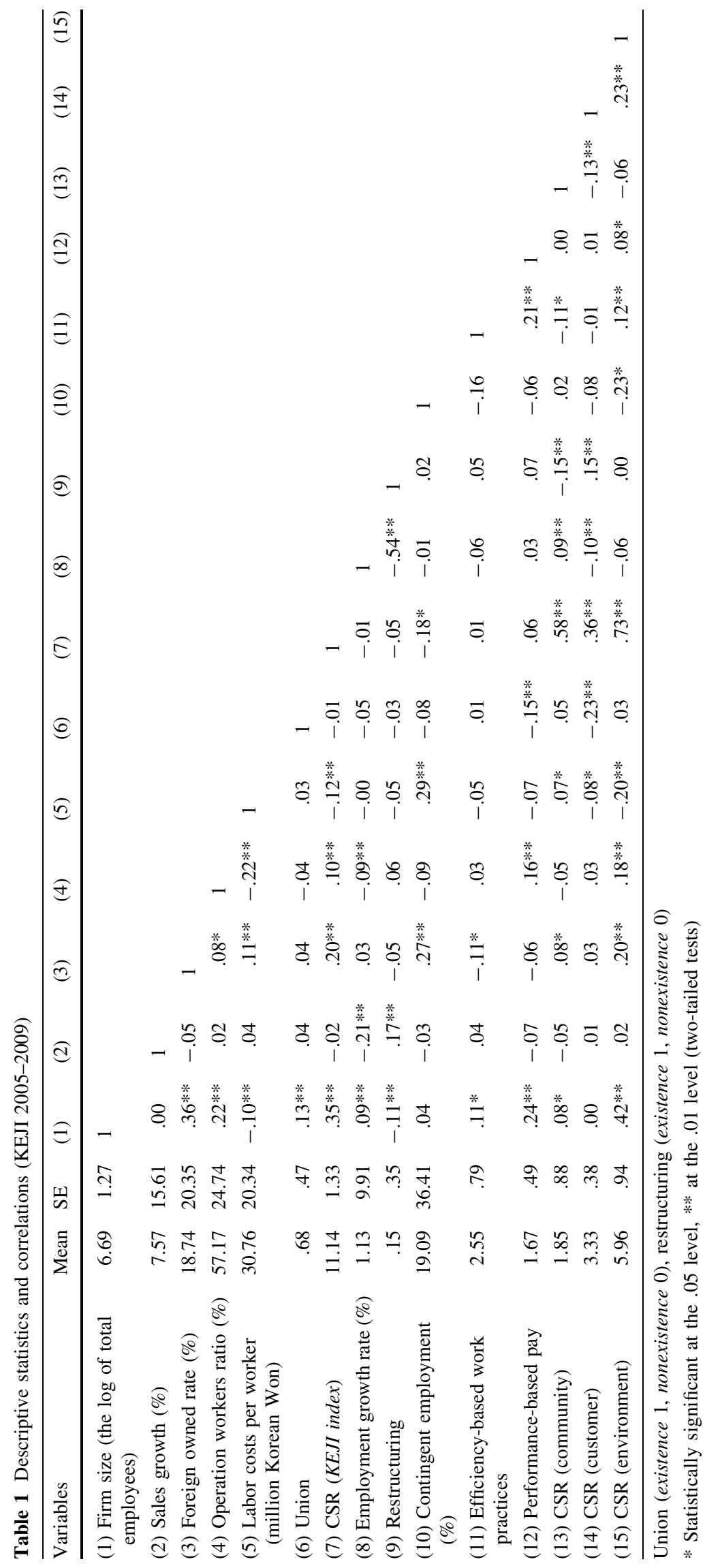




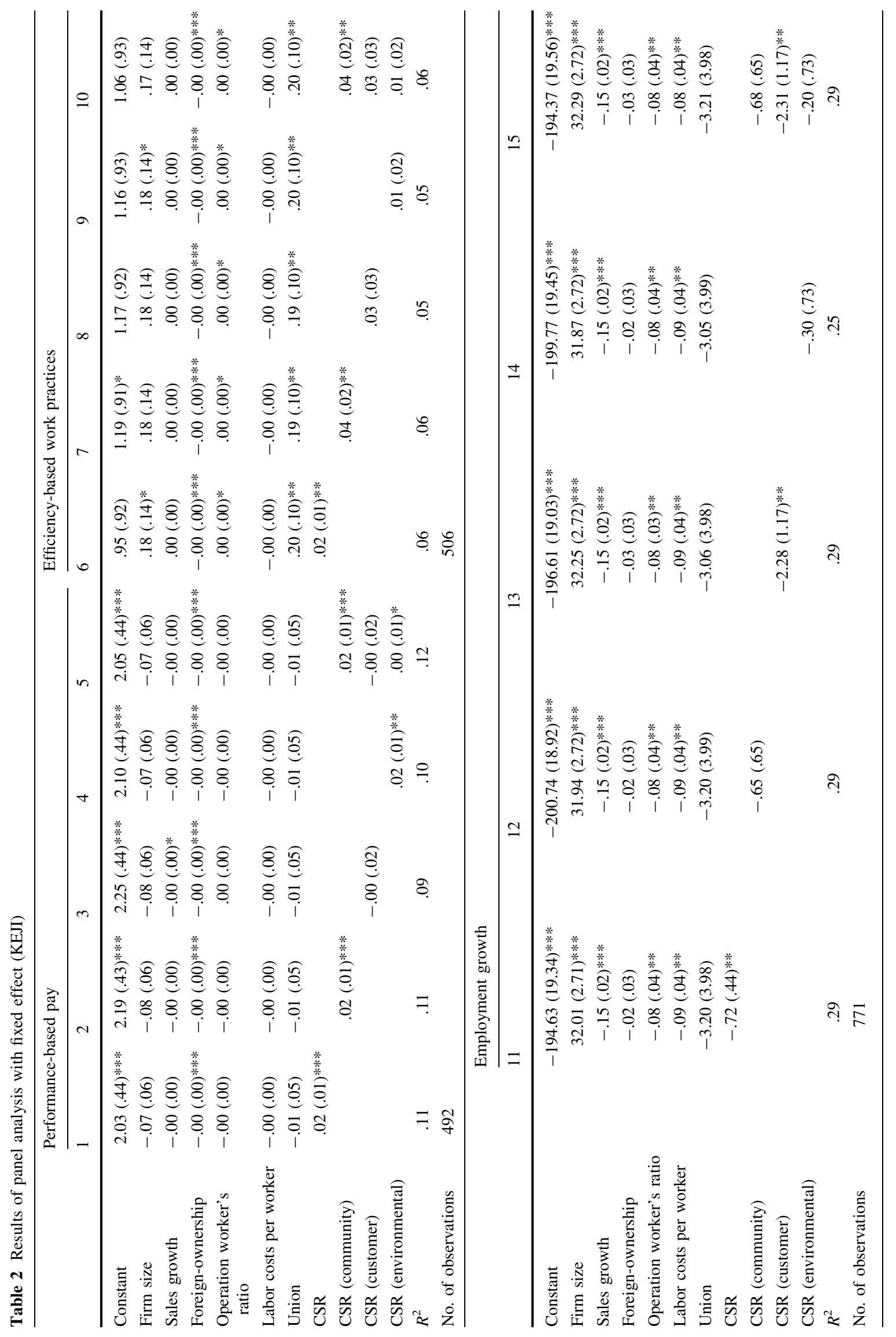




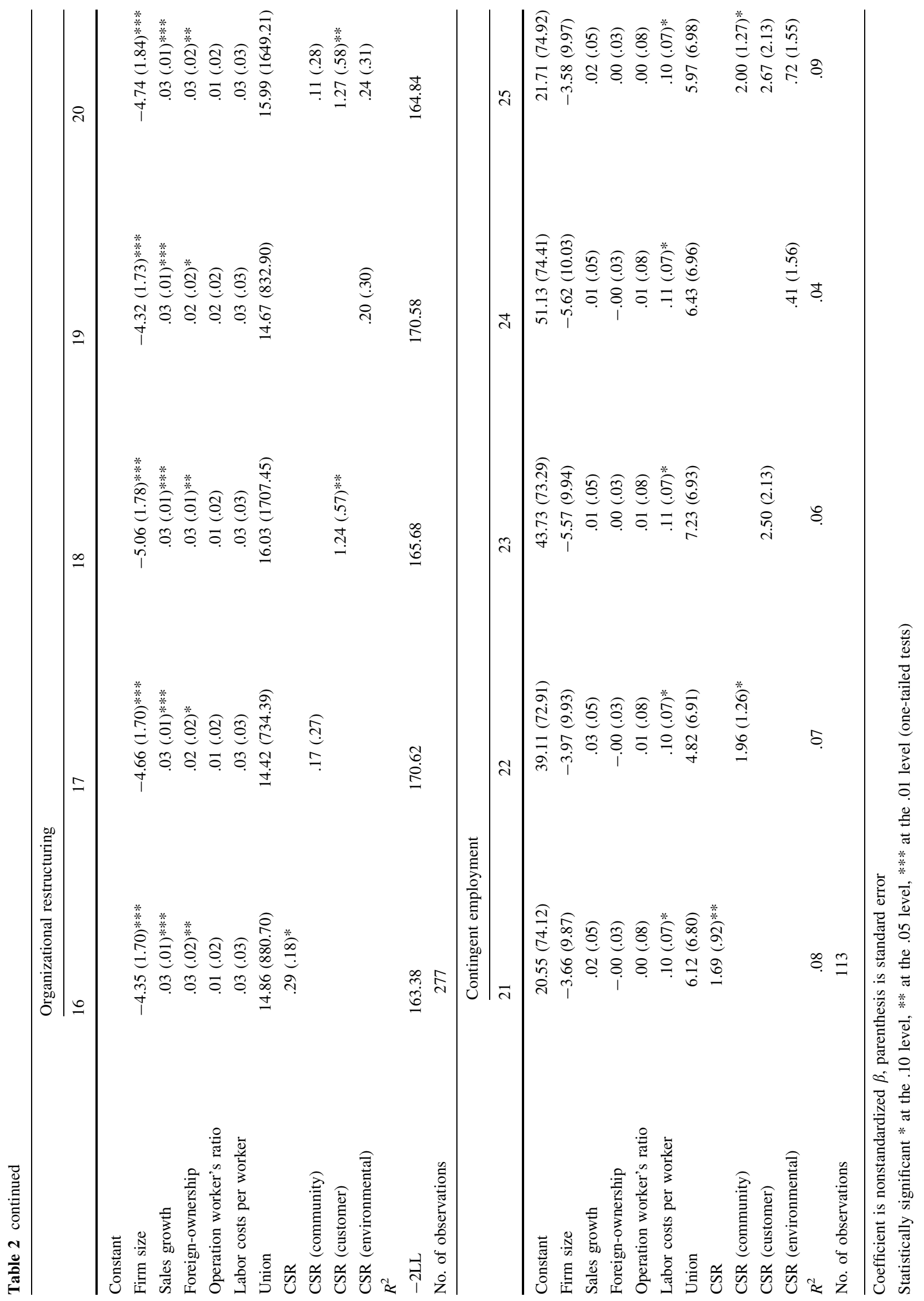


and employee growth was revealed to be both negative and significant $\left(\beta=-.72, p<.05, R^{2}=.29\right)$, indicating that firms engaged in CSR tended to hesitate in hiring new employees, possibly because of the financial constraints imposed by the commitment to CSR. Regarding the relationship between CSR and organizational restructuring, the result of logistic regressions exhibited a positive and significant association $(\beta=.29, p<.10,-2 \mathrm{LL}=163.38)$ between CSR and organizational restructuring. This finding implies that firms rated higher for CSR engaged more actively in restructuring than firms with lower CSR scores. This finding is consistent conceptually with the negative relationship of CSR with employment growth. Taken together, these results indicate that CSR based on external social issues may negatively influence employment growth and employment security. Finally, the impact of CSR on contingent employment likewise exhibited a positive and significant relationship $\left(\beta=1.69, p<.05, R^{2}=.08\right)$, suggesting that firms with CSR are more likely to use contingent workers than firms without CSR. Overall, these findings suggest that firms involved in CSR tend to rely on labor flexibility to offset social costs.

Again, we separately investigated the effects of each category of CSR on employment relations. CSR initiative for customer satisfaction showed significant and anticipated relationships with employment growth and organizational restructuring. Also, CSR initiative for community relations also showed significant and anticipated positive relationships with contingent employment. In other regression equations, regression coefficients generally showed expected, but insignificant, signs. Overall, the results tend to indicate that the more the firms participated in external CSR activities, the more they implemented strategies to minimize labor costs.

Despite the above findings, there can be concerns over the generalizability of this sample. The present study constrained the sample to firms which had robust CSR programs according to the KEJI index. By limiting the sample to only those firms which had appeared in the top 200 list at least twice, the sampling methods produced a biased sample with regard to CSR performance. The low standard deviation of CSR relative to its mean revealed this tendency. Although one can assert that this renders the finding of the association between CSR and employment relations outcomes even more impressive statistically since the present analysis dealt with such little variation in the variable, we have to acknowledge the problem of generalizability.

\section{Study 2}

To remedy the generalizability problem of Study 1, we conducted Study 2 utilizing a presumably less biased dataset with very different measures of CSR.
Sampling

In Study 2, we examined the effects of CSR on the same dependent variables using longitudinal data drawn from the Korean Workplace Panel Survey (KWPS). This survey was conducted by the Korea Labor Institute (KLI), a government-funded labor research group. The WPS dataset includes workplaces selected by stratified sampling of all establishments with more than 30 employees. The KWPS was administered at 290 public enterprises and 1615 private firms. Thus, the collected data are regarded to be nationally representative sample of Korean firms. A survey has been conducted biennially since 2005 in over 1905 workplaces and completed through face-to-face interviews with HR managers, IR managers, and employee representatives or union leaders. Specifically, HR managers responded to questions about CSR activities and HR practices such as performance-based pay and efficiencybased work practices, and contingent employment.

In the current analysis, we used datasets from 2007, 2009, and 2011. Although the KWPS has been conducted four times since 2005, questions about CSR activities were begun in 2007. Thus, we use the data except for 2005. On the other hand, we excluded firms with multiple workplaces because some information, including financial data (e.g., labor costs) is difficult to infer in firms with multiple workplaces. Our analysis therefore includes only firms that have a single workplace. Finally, we excluded public (i.e., state-owned) enterprises from our analysis because public enterprises primarily pursue public interests rather than organizational efficiency, and this theoretical framework is inapplicable to public enterprises. Notably, CSR involvements in public enterprises can be undertaken to comply with government regulations rather than a firm's profit-maximizing voluntary decision.

\section{Measures}

In Study 2, the measure of CSR, performance-based pay, efficiency-based work practices, and contingent employment were collected from the KWPS dataset. Performancebased pay, efficiency-based work practices, restructuring, and contingent employment were measured by the same measures as those used for Study 1. All other control variables were also obtained from the same data sources as those of Study 1. In addition, we controlled for 10 industry dummy variables (i.e., manufacturing, education, transportation, service, construction, bank, retail, publication, broadcasting, and engineering industries). Unlike the KEJI index in Study 1, the KWPS data provide solutions to three institutional questions to measure CSR involvement: (1) whether a firm has mid- and long-term plans to conduct CSR programs; (2) whether a firm has codes of conduct in implementing CSR activities, and (3) whether a firm 
operates an independent (stand-alone) department for CSR programs. For example, respondents were asked the following question: "Does your company have mid- and long-term plans for CSR actions?" All responses were coded as 1 or 0 . We summed responses for the three items as a measure for CSR involvement. Factor analysis indicated assignment of an Eigen value of 1.83 for a single item comprised of CSR involvement and loadings, .87 for plans for CSR, .88 for codes of conduct for CSR, and .89 for an independent department for CSR. Cronbach's alpha for all items was .84 , which was acceptable for statistical analyses. The measures of performance-based pay, efficiency-based work practices, and contingent employment were identical in both Study 1 and Study 2 .

\section{Analyses}

We used STATA (13.0 version) for unbalanced panel data analysis. A random effects model was estimated in study 2 . Since the present analyses dealt with the stratified sample of firms in Korean firms, random effect models were deemed more appropriate (Borenstein et al. 2011).

\section{Results}

Descriptive statistics and bivariate correlations for variables used in Study 2 are presented in Table 3.

All proposed hypotheses except for Hypothesis 4 were empirically supported. The first column of Table 4 presented the relationships between CSR and performance-based pay. The regression coefficient of the CSR variable was both positive and significant $\left(\beta=.08, p<.05, R^{2}=.28\right)$. The second column showed that CSR has both a positive and significant relation with efficiency-based work practices ( $\left.\beta=.25, p<.01, R^{2}=.29\right)$. In the third column, the relationship between CSR and employee growth was shown to have a negative and significant association $(\beta=-1.14$, $p<.10, R^{2}=.33$ ). The fourth column indicates the relationship between CSR and organizational restructuring, and the result of the logistic regressions revealed no significant association between CSR and organizational restructuring. The fifth column presents the impact of CSR on contingent employment. The results again reveal a positive and significant relationship between CSR and the contingent employment variable $\left(\beta=1.02, p<.05, R^{2}=.14\right)$. All of the findings in Study 2 were consistent with those of Study 1 except for organizational restructuring.

\section{Discussion and Conclusions}

This paper used two Korean firm-level panel datasets to test the effects of CSR involvement on employment-

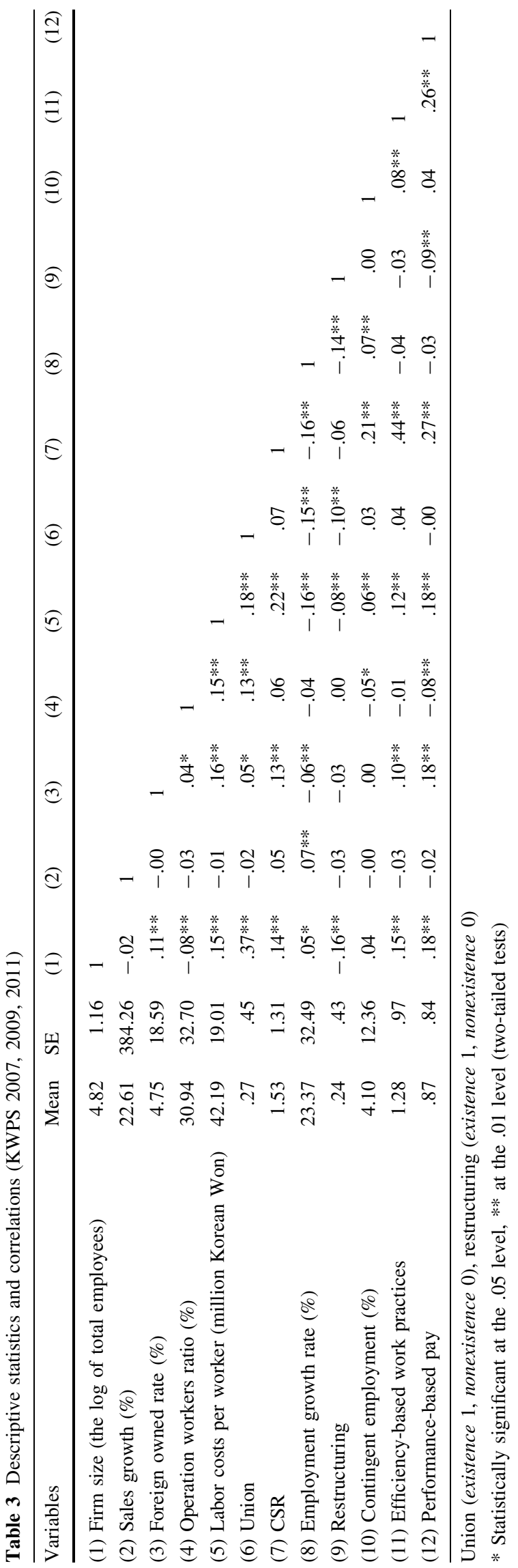


Table 4 Results of panel analysis with random effect (KWPS 2007, 2009, 2011 year)

\begin{tabular}{|c|c|c|c|c|c|}
\hline & $\begin{array}{l}1 \\
\text { Performance- } \\
\text { based pay }\end{array}$ & $\begin{array}{l}2 \\
\text { Efficiency-based } \\
\text { work practices }\end{array}$ & $\begin{array}{l}3 \\
\text { Employment } \\
\text { growth }\end{array}$ & $\begin{array}{l}4 \\
\text { Organizational } \\
\text { restructuring }\end{array}$ & $\begin{array}{l}5 \\
\text { Contingent } \\
\text { employment }\end{array}$ \\
\hline Constant & $-.27(.49)$ & $.76(.50)^{*}$ & $9.49(12.05)$ & $3.44(1.75)^{* *}$ & $8.43(6.91)$ \\
\hline Industry (education) & $-.12(.47)$ & $.19(.31)$ & $-7.17(7.36)$ & $-23.72(110273.70)$ & $-2.35(4.22)$ \\
\hline Industry (transportation) & $-.54(.20)^{* * *}$ & $-.68(.18)^{* * *}$ & $-.68(4.48)$ & $-1.66(.80)^{* *}$ & $-6.63(2.58)^{* * *}$ \\
\hline Industry (service) & $.17(.19)$ & $.69(.19) * * *$ & $.98(4.64)$ & $-1.61(.82)^{* *}$ & $-2.06(2.67)$ \\
\hline Industry (construction) & $.08(.26)$ & $.61(.23) * * *$ & $-1.30(5.68)$ & $.78(.59)^{*}$ & $1.18(3.28)$ \\
\hline Industry (bank) & $.57(.42)^{*}$ & $.45(.48)$ & $7.26(11.84)$ & $.26(1.23)$ & $.80(6.82)$ \\
\hline Industry (retail) & $.29(.21)^{*}$ & $.39(.22)^{* *}$ & $-4.70(5.58)$ & $.92(.57)^{*}$ & $6.65(3.21)^{* *}$ \\
\hline Industry (publication) & $-.44(.20)^{* *}$ & $.05(.20)$ & $13.49(4.80)^{* * *}$ & $.34(.51)$ & $-5.17(2.76) * *$ \\
\hline Industry (broadcasting) & $.19(.22)$ & $.02(.22)$ & $.68(5.42)$ & $.17(.59)$ & $-5.98(3.12)^{* *}$ \\
\hline Industry (engineering) & $-.31(.21)^{*}$ & $.16(.21)$ & $-6.43(5.24)$ & $-.01(.62)$ & $-6.86(3.02)^{* *}$ \\
\hline Firm size & $.16(.07)^{* *}$ & $.02(.08)$ & $5.33(1.83)^{* * *}$ & $-.62(.27)^{* *}$ & $-.38(1.05)$ \\
\hline Sales growth & $-.00(.00)$ & $-.00(.00)$ & $.01(.01)$ & $.00(.00)^{*}$ & $.00(.01)$ \\
\hline Foreign-ownership & $.00(.00)^{*}$ & $.00(.00)^{*}$ & $-.04(.05)$ & $-.01(.01)^{*}$ & $.02(.03)$ \\
\hline Operation worker's ratio & $.00(.00)$ & $.00(.00)^{*}$ & $-.03(.05)$ & $.00(.01)$ & $-.04(.03)^{*}$ \\
\hline Labor costs per worker & $.01(.00)^{* *}$ & $.00(.00)$ & $-.23(.06)^{* * *}$ & $-.02(.01)^{* *}$ & $-.01(.03)$ \\
\hline Union & $-.22(.12)^{* *}$ & $.07(.11)$ & $-12.14(2.73)^{* * *}$ & $-.52(.35)^{*}$ & $2.69(1.56)^{* *}$ \\
\hline CSR & $.08(.04)^{* *}$ & $.25(.038)^{* * *}$ & $-1.14(.83)^{*}$ & $.00(.12)$ & $1.02(.47)^{* *}$ \\
\hline$R^{2}$ & .28 & .29 & .33 & & .14 \\
\hline$-2 \mathrm{LL}$ & & & & 168.12 & \\
\hline No. of observations & 288 & 416 & 416 & 416 & 416 \\
\hline
\end{tabular}

Coefficient is nonstandardized $\beta$. Parenthesis is standard error. Industry manufacturing dummy variable is reference variable Statistically significant $*$ at the .10 level, $* *$ at the .05 level, $* * *$ at the .01 level (one-tailed tests)

related issues. Major findings include CSR involvement (1) facilitates employer tendency to use performance-based pay and efficiency-based work practices, (2) has a negative association with employment growth, and (3) showed a positive relationship with increased labor flexibility through restructuring and/or contingent employment.

The present quantitative findings support the results of previous qualitative studies. Royle's (2005) case study found a positive correlation between CSR and performance-oriented payment systems, and Vitaliano and Stella (2006) identified a positive relationship between CSR involvement and efficiency-based work practices. The positive association between CSR and labor flexibility was manifested in several qualitative studies (Benson 2008; Bonvin 2007; Smith and Helfgott 2010). However, while previous studies analyzing CSR and employment relations relied largely on a small set of cases, the present study enhances the generalizability of these earlier studies. This enhancement is owed to the adoption of multivariate panel analyses that used two relatively large datasets each covering a 5-year period.

The results of this study accordingly have theoretical implications. First, our findings support the argument that as institutional pressures mount for explicit CSR behavior such as charitable donations, firms tend to introduce CSR activities as window dressing (Matten and Moon 2008). As Freeman (1994) stated, these firms seem to suffer from the "separation thesis" or "separation fallacy" that there is disconnect between business and ethics, or in this case "doing well" and "doing good." These findings imply that participation in corporate social activities may not necessarily represent a commitment to do the right thing, but instead can be associated with mobilizing internal resources in response to the costs of CSR actions undertaken because of institutional pressure.

Some have argued that CSR activities can lead to cooperative labor-management relations, improve organizational identity, and commitment (Bhattacharya et al. 2008; Brammer et al. 2007; Deakin and Whittaker 2007; Jones 2010; Turker 2009). The empirical findings of the present study, however, seem to stand in contrast to this argument. In reality, CSR commitment to social issues seems to impose additional costs, and in response, firms with limited resources appear to mobilize resources even by undermining the interests of internal stakeholders. Apparently, the view arguing the positive impacts of CSR on 
employment relations, which overlooks the role of limited resources in terms of CSR involvement, can lead to assertions that tend to be too positivistic and rather unrealistic.

Second, the present study clearly emphasizes the importance of enterprise resources available for allocation to various competing demands. Our evidence indicates that managerial options concerning CSR may be restricted in the face of insufficient resources. Management appears to resort to improvements in internal efficiency and minimization of labor costs as ways to marshal resources to offset costs associated with externally oriented CSR activities designed to both bolster a firm's reputation and secure its social legitimacy. The present study suggests that, when confronted with limited resources and competing demands, management is more likely to meet external social demands than address demands for employment security of internal stakeholders.

Third, the present study tends to suggest two contrasting faces of CSR. At the same time management attempts to be projected as "a good neighbor" by committing to socially desirable behavior, it appears "a bad employer" by undermining the employment security of its own employees. The present study implied that external CSR activities and internal CSR activities may have a substitutive (instead of complementary) relationship. The present study suggests why in many cases an employer's commitment to social issues does not go hand in hand with employee interests. Similarly, it attempts to explain why external CSR activity is often incompatible with internal CSR. Our findings imply that although firms are pressured to undertake socially responsible positions toward both internal stakeholders and society as a whole, the real world of limited resources makes this balance of CSR difficult to achieve.

The results of the present study could be inconsistent with the findings of the meta-analysis by Orlitzky et al. (2003) that showed that good social performance and higher financial performance are broadly correlated. In this regard, an interesting suggestion for future research might be to examine the firms which show the opposite relationship between CSR and employment practices to the one we find in our sample, and to see what these firms do to maintain good employment practices, while also implementing external facing CSR programs. That is, researchers need to look at some individual cases where firms get these variables to move positively together. It will be useful to find out what programs these firms are implementing to meet increased cost pressures for CSR programs.

This study has practical implications for policymakers and management. First, our results suggest that policy makers should understand the limited (or even negative) role of CSR (or at least the current form of CSR) in enhancing labor rights. In many countries, governments have increased deregulation and decreased their own role in protecting labor rights. Accordingly, employers' discretional responsibility to their employees has increased. Competitive market pressures and limited resources, however, lead to unbalanced CSR practices between external and internal responsibilities, and most firms involved in CSR do not guarantee the rights of internal stakeholders. In particular, in emerging markets where labor regulations are weaker than those of developed countries, the problem can be even graver. Where this is the case, governments have to be more active in protecting labor rights and working conditions instead of relying on private sector CSR activities.

Second, employers should cultivate a more balanced approach to CSR. Although harmonizing the interests of all stakeholders is a difficult (if not impossible) task, sacrificing the interests of internal stakeholders to meet social demands may lead to undesirable consequences in labor relations (McAdam and Leonard 2003). A long-term perspective that seeks to maintain a balance of CSR activity between social issues and employee issues may help sustain a firm's growth.

The limitations of the present study should be mentioned. Because our sample included firms in a single country, Korea, nation-specific characteristics may have affected our results. Thus, our findings should be carefully interpreted before any attempt is undertaken to generalize the results of this paper. The present study (especially Study 1) addresses only three dimensions of CSR: community relations, customer satisfaction, and environmental protection to the exclusion of other dimensions of CSR such as suppliers and financiers. Since the present study did not adopt a holistic approach toward CSR, the findings of the present study may indicate only that a firms' investment in external CSR (in the areas of community, customer, and environment) has a negative relationship with internal CSR in the areas of employment relations.

The present study did not test the causal relationship between these two variables (i.e., CSR and employment practices) and only found temporary associations between the two. Thus, one has to be circumspect in asserting that the investment in CSR is driving the changing employment practices and slower hiring growth. In this regard, future research should be helpful to understand if there is a casual linkage between these two phenomena: CSR and employment practices. Some qualitative work may be desirable to find out whether firms really are making an explicit tradeoff, and to understand fully why managers believe they have to make this trade-off.

Acknowledgments This research was partially supported by the IBRE Research Fund of Korea University Business School. 
Open Access This article is distributed under the terms of the Creative Commons Attribution License which permits any use, distribution, and reproduction in any medium, provided the original author(s) and the source are credited.

\section{References}

Abowd, J. M. (1990). Does performance-based managerial compensation affect corporate performance? Industrial and Labor Relations Review, 43(3), 52-73.

Ahmadjian, C. L., \& Robinson, P. (2001). Safety in numbers: Downsizing and the deinstitutionalization of permanent employment in Japan. Administrative Science Quarterly, 46(4), 622-654.

Aupperle, K. E., Carroll, A. B., \& Hatfield, J. D. (1985). An empirical examination of the relationship between corporate social responsibility and profitability. Academy of Management Journal, 28(2), 446-463.

Baltagi, B. (2008). Econometric analysis of panel data (Vol. 1). New York: Wiley.

Behrman, J. R., \& Wolfe, B. L. (1989). Does more schooling make women better nourished and healthier? Adult sibling random and fixed effects estimates for Nicaragua. Journal of Human Resources, 24(4), 644-663.

Benson, P. (2008). Good clean tobacco: Philip Morris, bio capitalism, and the social course of stigma in North Carolina. American Ethnologist, 35(3), 357-379.

Bhattacharya, C. B., Sen, S., \& Korschun, D. (2008). Using corporate social responsibility to win the war for talent. MIT Sloan Management Review, 49(2), 37-44.

Bonvin, J. M. (2007). Corporate social responsibility in a context of permanent restructuring: A case study from the Swiss metal working sector. Corporate Governance: An International Review, 15(1), 36-44.

Borenstein, M., Hedges, L. V., Higgins, J. P., \& Rothstein, H. R. (2011). Introduction to meta-analysis. West Sussex: Wiley.

Brammer, S., Millington, A., \& Rayton, B. (2007). The contribution of corporate social responsibility to organizational commitment. The International Journal of Human Resource Management, 18(10), 1701-1719.

Brown, C. (1990). Firms' choice of method of pay. Industrial and Labor Relations Review, 43, 165-182.

Campbell, J. L. (2007). Why would corporations behave in socially responsible way? An institutional theory of corporate social responsibility. Academy of Management Review, 32(3), 946-967.

Carroll, A. B. (1979). A three-dimensional conceptual model of corporate performance. Academy of Management Review, 4(4), 497-505.

Carroll, A. B. (1991). The pyramid of corporate social responsibility: Toward the moral management of organizational stakeholders. Business Horizons, 34(4), 39-48.

Choi, J. S., Kwak, Y. M., \& Choe, C. (2010). Corporate social responsibility and corporate financial performance: Evidence from Korea. Australian Journal of Management, 35(3), 291-311.

Cochran, P. L., \& Wood, R. A. (1984). Corporate social responsibility and financial performance. Academy of Management Journal, 27(1), 42-56.

Cooper, S. M., \& Owen, D. L. (2007). Corporate social reporting and stakeholder accountability: The missing link. Accounting, Organizations and Society, 32(7), 649-667.

Cottrill, M. T. (1990). Corporate social responsibility and the marketplace. Journal of Business Ethics, 9(9), 723-729.

De Roeck, K., Marique, G., Stinglhamber, F., \& Swaen, V. (2014). Understanding employees' responses to corporate social responsibility: Mediating roles of overall justice and organisational identification. The International Journal of Human Resource Management, 25(1), 91-112.

Deakin, S., \& Hobbs, R. (2007). False dawn for CSR? Shifts in regulatory policy and the response of the corporate and financial sectors in Britain. Corporate Governance: An International Review, 15(1), 68-76.

Deakin, S., \& Whittaker, D. H. (2007). Re-embedding the Corporation? Comparative perspectives on corporate governance, employment relations and corporate social responsibility. Corporate Governance: An International Review, 15(1), 1-4.

Delery, J. E., \& Doty, D. H. (1996). Modes of theorizing in strategic human resource management: Tests of universalistic, contingency, and configurational performance predictions. Academy of Management Journal, 39(4), 802-835.

Evans, D. S. (1987). Tests of alternative theories of firm growth. The Journal of Political Economy, 95(4), 657-674.

Falck, O., \& Heblich, S. (2007). Corporate social responsibility: Doing well by doing good. Business Horizons, 50(3), 247-254.

Federation of Korean Industries. (2011). The ethical business reports on results of CSR. Seoul: Federation of Korean Industries.

Fenwick, T., \& Bierema, L. (2008). Corporate social responsibility: Issues for human resource development professionals. International Journal of Training and Development, 12(1), 24-35.

Freeman, R. E. (1984). Strategic management: A stakeholder approach. Boston: Pitman Publishing.

Freeman, R. E. (1994). The politics of stakeholder theory: Some future directions. Business Ethics Quarterly, 4, 409-421.

Graves, S. B., \& Waddock, S. A. (1994). Institutional owners and corporate social performance. Academy of Management Journal, 37(4), 1034-1046.

Guest, D. E., \& Woodrow, C. (2012). Exploring the boundaries of human resource managers' responsibilities. Journal of Business Ethics, 111(1), 109-119.

Hillman, A. J., \& Keim, G. D. (2001). Shareholder value, stakeholder management, and social issues: What's the bottom line? Strategic Management Journal, 22(2), 125-139.

Huselid, M. (1995). The impact of human resource management practices on turnover, productivity, and corporate financial performance. Academy of Management Journal, 38(3), 635-672.

Ichniowski, C., Kochan, T. A., Levine, D., Olson, C., \& Strauss, G. (1996). What works at work: Overview and assessment. Industrial Relations: A Journal of Economy and Society, 35(3), 299-333.

Inyang, B. J., Awa, H. O., \& Enuoh, R. O. (2011). CSR-HRM nexus: Defining the role engagement of the human resources professionals. International Journal of Business and Social Science, 2(5), 118-126.

Jamali, D., \& Mirshak, R. (2007). Corporate social responsibility (CSR): Theory and practice in a developing country context. Journal of Business Ethics, 72(3), 243-262.

Jamali, D., Sidani, Y., \& El-Asmar, K. (2009). A three country comparative analysis of managerial CSR perspectives: Insights from Lebanon, Syria and Jordan. Journal of Business Ethics, 85(2), 173-192.

Jones, D. A. (2010). Does serving the community also serve the company? Using organizational identification and social exchange theories to understand employee responses to a volunteerism programme. Journal of Occupational and Organizational Psychology, 83(4), 857-878.

Jones, M., Marshall, S., \& Mitchell, R. (2007). Corporate social responsibility and the management of labour in two Australian mining industry companies. Corporate Governance: An International Review, 15(1), 57-67.

Kim, D. M., \& Choi, I. (2013). A comparison of young publics' evaluations of corporate social responsibility practices of 
multinational corporations in the United States and South Korea. Journal of Business Ethics, 113(1), 105-118.

Korea Eximbank. (2012). Abroad investment statistics. Seoul: Korea Eximbank.

Lee, H.-J., Iijima, Y., \& Reade, C. (2011). Employee preference for performance-related pay: Predictors and consequences for organizational citizenship behaviour in a Japanese firm. The International Journal of Human Resource Management, 22(10), 2086-2109.

Mahoney, L. S., \& Thorne, L. (2005). Corporate social responsibility and long-term compensation: Evidence from Canada. Journal of Business Ethics, 57(3), 241-253.

Margolis, J. D., \& Walsh, J. P. (2003). Misery loves companies: Rethinking social initiatives by business. Administrative Science Quarterly, 48(2), 268-305.

Matten, D., \& Moon, J. (2008). "Implicit" and "explicit" CSR: A conceptual framework for a comparative understanding of corporate social responsibility. Academy of Management Review, 33(2), 404-424.

McAdam, R., \& Leonard, D. (2003). Corporate social responsibility in a total quality management context: Opportunities for sustainable growth. Corporate Governance, 3(4), 36-45.

McWilliams, A., \& Siegel, D. (2000). Corporate social responsibility and financial performance: Correlation or misspecification? Strategic Management Journal, 21(5), 603-609.

McWilliams, A., \& Siegel, D. (2001). Corporate social responsibility: A theory of the firm perspective. Academy of Management Review, 26(1), 117-127.

Neumark, D., \& Cappelli, P. (1999). Do "high performance" work practices improve establishment-level outcomes? National Bureau of Economic Research (No. 7374).

Origo, F. (2009). Flexible pay, firm performance and the role of unions. New evidence from Italy. Labour Economics, 16(1), 64-78.

Orlitzky, M., Schmidt, F. L., \& Rynes, S. L. (2003). Corporate social and financial performance: A meta-analysis. Organization Studies, 24(3), 403-441.

Osterman, P. (1994). Supervision, discretion, and work organization. The American Economic Review, 84(2), 380-384.

Parkinson, J. (2003). Disclosure and corporate social and environmental performance: Competitiveness and enterprise in a broader social frame. Journal of Corporate Law Studies, 3(1), 3-39.

Paul, C. J., \& Siegel, D. S. (2006). Corporate social responsibility and economic performance. Journal of Productivity Analysis, 26(3), 207-211.

Pava, M. L., \& Krausz, J. (1996). The association between corporate social-responsibility and financial performance: The paradox of social cost. Journal of Business Ethics, 15(3), 321-357.
Porter, M. E., \& Kramer, M. R. (2006). The link between competitive advantage and corporate social responsibility. Harvard Business Review, 84(12), 78-92.

Rodrigo, P., \& Arenas, D. (2008). Do employees care about CSR programs? A typology of employees according to their attitudes. Journal of Business Ethics, 83(2), 265-283.

Royle, T. (2005). Realism or idealism? Corporate social responsibility and the employee stakeholder in the global fast-food industry. Business Ethics: A European Review, 14(1), 42-55.

Shin, S., Kim, D.-O., \& Lee, K. (2014). Modern employment relations (6th ed.). Seoul: Bak Young Sa.

Slaughter, M. J. (2007). Globalization and declining unionization in the United States. Industrial Relations: A Journal of Economy and Society, 46(2), 329-346.

Smith, J., \& Helfgott, F. (2010). Flexibility or exploitation? Corporate social responsibility and the perils of universalization. Anthropology Today, 26(3), 20-23.

Sternberg, E. (1997). The defects of stakeholder theory. Corporate Governance: An International Review, 5(1), 3-10.

Turker, D. (2009). How corporate social responsibility influences organizational commitment. Journal of Business Ethics, 89(2), 189-204.

Ullmann, A. A. (1985). Data in search of a theory: A critical examination of the relationships among social performance, social disclosure, and economic performance of US firms. Academy of Management Review, 10(3), 540-557.

Vitaliano, D. F., \& Stella, G. P. (2006). The cost of corporate social responsibility: The case of the Community Reinvestment Act. Journal of Productivity Analysis, 26(3), 235-244.

Vogel, D. (2006). The market for virtue: The potential and limits of corporate social responsibility. Washington, DC: The Brookings Institution.

Waddock, S. A., \& Graves, S. B. (1997). The corporate social performance. Strategic Management Journal, 8(4), 303-319.

Welford, R. (2005). Corporate social responsibility in Europe, North America and Asia. Journal of Corporate Citizenship, 17(1), $33-52$.

Wood, D. J. (1991). Corporate social performance revisited. Academy of Management Review, 16(4), 691-718.

Zenisek, T. J. (1979). Corporate social responsibility: A conceptualization based on organizational literature. Academy of Management Review, 4(3), 359-368.

$\mathrm{Zu}$, L., \& Song, L. (2009). Determinants of managerial values on corporate social responsibility: Evidence from China. Journal of Business Ethics, 88(1), 105-117. 